\title{
Formation of the estimation system of the innovative activity in the regions of South Russia
}

\author{
Vladimir Viktorovich Kurchenkov \\ Volgograd State University, \\ Institute of Management and Regional Economics, \\ Volgograd, Russia \\ kurchenkov@volsu.ru
}

\author{
Hans-Christian Brauweiler \\ Western Saxon University of Applied Sciences, \\ Faculty of Economics, \\ Zwickau, Germany \\ christian.brauweiler@fh-zwickau.de
}

\author{
Larisa Vladimirovna Ponomareva \\ Volgograd State University, \\ Institute of Management and Regional Economics, \\ Volgograd, Russia \\ larisa.ponomareva@volsu.ru
}

\begin{abstract}
The article considers the features of the formation of a system for assessing the innovative activity of the South Russia regions, based on integral indicators and taking into account the criteria for absolute and relative innovation activity, the reasons for low innovation activity of Russian enterprises associated with a deficit of investment resources, as well as a high degree of monopolization of regional markets.
\end{abstract}

Keywords - innovations, innovation activity, innovation activity level, absolute innovations, relative innovations, innovation policy of the region

\section{INTRODUCTION}

Increasing of the innovation activity of Russian enterprises is one of the top priorities of the long-term planning strategy in Russia in the near future. The world economy's globalization intensifies competition on the external and internal markets, thus, it is necessary to modernize the existing production system and shift to innovation technologies in order to increase the Russian enterprises' competitiveness.

Unfortunately, nowadays Russia lags behind the leading world economies in developing its innovation potential. R\&D budget is being reduced, the innovation potential of industrial enterprises of the leading economic spheres is rather low [1]. The R\&D budget is quite low in comparison with the research allocations in foreign countries.

Many local and foreign researchers devoted their works to the study of this issue; however there are points in this sphere, which still remain uncovered. In particular, not all factors that influence the level of innovative activity in peripheral regions are always fully taken into account, the nature of the innovations used on the assumption of their absolute and relative advantages with respect to the world analogues is not properly considered.

\section{MATERIALS AND Methods (MODEL)}

Nowadays there is a system of statistic indicators, which reflects the enterprises' innovation activity level in a region. In particular, the innovation activity is traditionally evaluated by the following indicators:

- $\quad$ studying and elaborating of new products, services and technologies;

- acquiring machines, equipment, technologies, patents, licenses;

- acquiring software;

- $\quad$ teaching and training the staff;

- $\quad$ marketing research;

- other types of preparing the production of new products $[1,2]$.

Analyzing the costs of these activities allows evaluating the region's enterprises' innovation activity level and comparing it to other regions. It is worth mentioning that an important indicator of the innovation activity in the region is the share of innovation production in the overall volume of production shipped by it sectors. The other important indicator is an enterprise's fixed assets renewal indicator.

However, for a complex assessment of the level of innovative activity in the region, an integral assessment is needed that reflects the aggregate of individual indicators of innovation activity of enterprises located in the region. To date, there is a sufficient number of techniques that integrate both the above-mentioned indicators imported from the official statistics database, and separately developed indicators. Among the existing methods for the formation of an integrated assessment of innovation activity, we can single out both the methods of domestic $[1,2,3,4,5]$, and foreign scientists $[6,7,8,9]$, which allow to calculate the number of 
important integral indicators reflecting the level of development of innovative potential, innovative infrastructure of the region, as well as the effectiveness of innovation. The advantage of these methods is their adaptability to the existing bases of official statistics, together with this it makes it possible to compare regions in a single group of complex commensurable indicators. These integral indicators make it possible to construct temporal dynamic series of innovative activity of regions in the long-term and short-term periods.

However, this methodology has its limitations, related, on the one hand, by integrating the indicators of innovation potential, the development of innovation infrastructure and directly the results of innovation activity, which do not always exactly correlate with each other. On the other hand, the degree of relativity of innovations being introduced is not taken into account, namely, this type of innovation is introduced for the first time, or a simulation model based on already created innovations is applied [5]. In accordance with this, it is worthwhile to assume that the overall integral index of innovation activity, based on the above methods, can be substantially adjusted.

It should be assumed that here it is necessary to take into account the proportion of relative and absolute innovations in the structure of all innovations in the region. And in this case, the indicator of the degree of relativity can be represented as the total ratio of absolute and relative innovations in the context of their types differences, based on the use of the multiplication dependence.

In particular, if this ratio is greater than 1 , the innovation relativity index can be 1.2 . If the ratio is less than 0.5 , (which will indicate a low share of absolute innovation), the innovation relativity index can be 0.8 . Thus, the greater the share of absolute innovation in value terms in the structure of innovation, the higher the actual level of innovation activity, which allows you to take into account the quality of innovation, and not just the overall quantitative parameters.

Also, while calculating the integral index of innovation activity, it is necessary to take into account the sectoral structure of the region, since initially the innovation activity in various industries is different, and also the scale of production. Since the introduction of innovations at large enterprises on a large scale allows to obtain a greater economic effect, which is also important to take into account when calculating the rating of innovation activity in the regions.

At the same time, the integral indicator of innovation activity in the region should be composed of two parts, or two subintegral indicators, taking into account the cost and efficient approaches. The first of them is determined on the basis of calculating the share of investment in various types of innovation in the total volume of investments (Ic). The second one is based on calculating the share of innovative products in the total volume of products, or the works and services performed (Iv). Accordingly, these subintegral indicators or indices of innovation activity can be calculated by the following formulas:

$$
\begin{aligned}
I_{c} & =\frac{\sum R_{n} * S_{n} * C_{n}}{n} \\
I_{v} & =\frac{\sum R_{n} * S_{n} * V_{n}}{n}
\end{aligned}
$$

Where,

Sn.- weighting coefficients for innovations of various types.

Rn. - the value of the multiplier, reflecting the degree of relativity of innovations.

$\mathrm{Cn}$ - the share of investments for innovations of various types in the total amount of investment costs for the period under review.

$\mathrm{Vn}$ - the share of innovative products, services and works in the total volume of shipped products, services and works performed.

In this case, the total integrated indicator or innovation activity index can be represented as follows:

$$
I_{i}=\frac{I_{c}+I_{v}}{2} K_{p} * K_{g}
$$

Where,

$\mathrm{Kp}$ - correlation coefficient, reflecting the scale of economic activity in the region.

Ks - correlation coefficient, reflecting the industrial structure of the regional economic complex.

The calculation of this indicator will make it possible to comprehensively assess the level of innovative activity in the regions of the South Russia, taking into account the type diversity of innovations, the economic specialization of the region, the degree of relativity of the innovations used, and the scale of their implementation.

\section{RESULTS AND DISCUSSION}

Research of innovative activity is expedient for carrying out on the example of peripheral regions of the South Russia. It should be noted that, in general, the regions of the Southern Federal District are not among the innovation development leaders (by the research intensity, research potential localization, innovation and investment activity levels)[3,4]. Nevertheless, it has a rather high innovation potential, which is characterized by the rich concentration of education and R\&D institutions, hi-tech sectors industrial enterprises (metallurgy, chemistry and petrochemical industry, machinery and so on). All these conditions provide favorable environment for developing the innovations in the region. 
At the same time, the efficiency of using R\&D and education potential of the regions is insufficient, while the region's innovation infrastructure formation is only in its initial stage. The analysis carried out has shown that the innovation indicators have been decreasing over the last years. What is more, most of the innovation costs (98\%) are allocated for the industry, while the agriculture, communication, trade are even less innovatively active. The main innovation activity type is acquiring equipment [10].

In general, in 2016, the level of innovation activity of organizations in the regions of the South Russia in terms of such indicators as the proportion of organizations that carried out innovative activities in the total number of organizations surveyed and the share of innovative goods and services in the total volume of shipped products and services and works performed was lower than the total Russian level and the Central Federal District leading in this group of indicators (Table 1).

Also, it should be noted that the bulk of the costs of innovation account for $98 \%$ of industry, while other branches of the national economy of agribusiness, communications, trade have even less innovative activity. The main type of innovation is the acquisition of equipment [5]. The existing structural priorities in the innovation activity in favor of the acquisition of machines and equipment to a certain extent determined a relatively low level of innovative activity.

TABLE I. INDICATORS OF INNOVATIVE ACTIVITY IN THE REGIONS OF THE SOUTH RUSSIA IN 2016.

\begin{tabular}{|c|c|c|}
\hline $\begin{array}{l}\text { Regions of the Southern } \\
\text { Federal District }\end{array}$ & $\begin{array}{l}\text { The share of } \\
\text { innovative and active } \\
\text { organizations in the } \\
\text { total number of } \\
\text { organizations } \\
\text { surveyed, in \% }\end{array}$ & $\begin{array}{l}\text { Ratio of the } \\
\text { volume of } \\
\text { innovative } \\
\text { goods and } \\
\text { services to the } \\
\text { total volume of } \\
\text { shipped goods, } \\
\text { works, services } \\
\text { in\%. }\end{array}$ \\
\hline Russian Federation & 8,4 & 8,5 \\
\hline Central Federal District & 10,3 & 11,6 \\
\hline South Federal District & 7,1 & 8,4 \\
\hline Republic of Adygea & 4,2 & 10,1 \\
\hline Republic of Kalmykia & 2,0 & 0,5 \\
\hline Republic of Crimea & 2,8 & 1,1 \\
\hline Krasnodar Territory & 9,1 & 7,7 \\
\hline Astrakhan Region & 9,1 & 5,8 \\
\hline Volgograd Region & 4,9 & 3,0 \\
\hline Rostov Region & 8,4 & 14,5 \\
\hline Sevastopol & 3,3 & 12,8 \\
\hline
\end{tabular}

Source: [10, p.1142-1144, p.1146 - 1148].

Analysis of innovation activity by integrated indicators can have different results. In particular, according to the method of
Kiselev V. N. [4], regions of SFD have insufficiently high composite index of innovation activity. According to this indicator, the SFD takes far from the first (penultimate) place among other Federal Districts (0.229.). In particular, the Central FD - 0,306, the Northwest FD - 0,279, the Volga Federal District - 0,316, the Ural FD - 0,238, the Siberian Federal District - 0,240, the Far East FD - 0,259, the North Caucasus FD - 0,121. This is explained by the low coefficient of location of elements of the national innovation system in the Southern Federal District in comparison with other federal districts, insufficiently developed industrial potential, primarily in the processing industries, which is one of the main sources or generators of innovative activity. As for individual regions of the Southern Federal District, the Volgograd region's composite index of innovation activity was 0.283 , which is higher than other regions, in particular the Rostov region - 0.228 and the Krasnodar Territory - 0.173 [4].

However, if the method under consideration in the federal districts gives a completely relevant picture, for some regions it is not completely. And this is due to the fact that, as noted, it does not take into account the degree of relativity of innovations, their specific diversity, the regional branch structure and the scale of industrial production in the region as a whole. In accordance with our two-component methodology that integrates cost-effective and efficient approaches, the integral index of innovation activity of the Volgograd region will be lower, and will be 0.19 , yielding at the same time to the Rostov region and the Krasnodar Territory, and not occupying a leading position in this indicator among other regions South of Russia. If this comparison is made with the regions of central Russia, the situation will be even more unstable.

Among the reasons for the insufficient innovation activity of enterprises and organizations in the Volgograd Region is the lack of investment resources for innovative development, an unfavorable investment climate, the disinterest of new owners to development of production, the underdevelopment of the innovation infrastructure, strong competitive pressure from foreign producers in domestic markets, legal insecurity of domestic innovation-active enterprises.

Along with the above-mentioned reasons for the low innovation activity of Russian enterprises, a high level of monopolization of regional markets should be highlighted. In general, if we imagine the regional economy in the form of competitive markets structure, then on average about $40 \%$ of enterprises will continue to exist in a competitive environment (Fig. 1). These are mainly small and medium enterprises.

However, as our research reveals, these companies have a fairly low innovation activity either, since they have a limited number of their own investment means needed for making innovations. There are not enough opportunities in Russia or attracting investment from external sources, first of all, venture capitals, compared with the developed countries [9]. 


\begin{tabular}{|c|}
\hline Oligopolistic market $\mathbf{- 3 0 \%}$ \\
\hline $\begin{array}{c}\text { Large local and foreign trans-national } \\
\text { companies }\end{array}$ \\
\hline $\begin{array}{c}\text { Competitive market } \mathbf{- 4 0 \%} \\
\text { Service, trade, agricultural and industrial } \\
\text { enterprises }\end{array}$ \\
\hline $\begin{array}{c}\text { Natural monopolies - 30\% } \\
\text { services and water supplies, housing }\end{array}$ \\
\hline
\end{tabular}

Fig. 1. Competitive relations structure on the internal market

In other words, the region's economy is in a weird situation: large enterprises have the innovative development and innovation stimulation resources, but do not have a stimulating competitive development factor, while small and medium-sized enterprises exist in a competitive environment, but do not have enough resources, primarily investment, for innovative development. This situation hinders the growth of economic entities' innovation activity at great extent.

\section{CONCLUSION}

Thus, the level of innovation activity is a decisive factor in the growth of competitiveness of both a separate economic organization and the region as a whole. However, in modern conditions, there is a need to develop an adequate system for assessing the level of innovation activity at the regional level because the existing methods do not take into account a number of important points. - first of all, the degree of relativity of applied innovations, the scale of industrial production in the region as a whole and the nature of its sectoral specialization. In accordance with this, it is worthwhile to assume that the overall integral index of innovation activity, taking into account these factors, can be substantially adjusted.

At the same time, there remains the problem of integrating cost-effective and efficient approaches, the potential and the result of innovation. This problem is also present while calculation of two well-known global innovation indices: Global Innovation Index and Bloomberg Innovation Index. Therefore, the use of a two-component methodology based on the integration of cost-effective and efficient approaches and taking into account the degree of relativity of innovations has become quite logical and justified in this study.

In the framework of this methodology, the integral indicator of innovation activity in the region was presented as the sum of two sub-integration indicators, one of which was determined on the basis of calculating the share of investment in various types of innovation in the total volume of investments. Another - on the basis of calculating the share of innovative products in the total output, or the work and services performed. The correlation coefficients used reflected the degree of dependence of the final indicator on the scale of economic activity in the region and on its sectoral structure. Regarding the inclusion of the degree of relativity of innovations, in this case, the indicator was presented as the total ratio of absolute and relative innovations in terms of their type differences, based on the use of the multiplication dependence.

Calculation of this indicator for the regions of the South Russia made it possible to establish that, despite the significant potential, the level of innovation activity remains insufficiently low compared with other regions. The main reasons for the lack of innovative activity in the Volgograd region today are the lack of investment resources, a suboptimal structure of industrial production in the region with a high share of the raw materials sector, the lack of interest of new owners in enhancing innovative activity of enterprises, the underdevelopment of the innovation infrastructure, etc. At the same time, the system of the adequate assessment of the innovation activity level of the region, provides the basis for the search for effective measures to increase it in the nearest future.

\section{References}

[1] Pavlycheva A.V. Innovative activity of Russian enterprises // Novainfo.ru. - 2016. - N 1. - No. 46. - C. 67-72.

[2] Mochalova K.M., Petergova A.V. Directions of development of innovative activity in industrial enterprises // Izvestia of the Moscow State Technical University MAMI. - 2015. - T. 5. - No. 4 (26). - P. 237 241.

[3] Duplenko N.G, Smirnova O.S. Sectoral and regional analysis of innovation activity of Russian enterprises // Bulletin of the Baltic Federal University.by I. Kant. Series: Humanities and Social Sciences. 2016. - No. 2. - P. 85-95.

[4] Kisselev V.N. Comparative analysis of innovation activity of RF subjects // Innovations. - 2010. - No. 4 (138). - from. 17-24.

[5] Kurchenkov V.V. The importance of the region's economic activity evaluation in Russia 2012-2016/ Kurchenkov V.V., Fetisova O.V., Orlova A.A., Gladkaya E.A. // Revista Galega de Economia - 2017 - N 26(3), - c.33-44.

[6] Brauweiler H.Ch. Innovationen im peripheren Raum. Eine Analyse am Beispiel der Granzraume Sud- und Ostsachsens / H.Ch.Brauweiler Mit einem Geleitv von Matthias Kramer - Wiesbaden: Dt.Univ.-Verlag, 2002. -141.

[7] Grabowska M. Selected directions in analysis of innovative activities in enterprises / M. Grabowska // Applied Mechanics and Materials. -2014. - T. 718. P. 50-55.

[8] Rubino, F.E. An innovative model for a sustainability report in no-profit organizations / F.E. Rubino, M. Rija, G. Bronzetti,. G. Sicoli, P. Tenuta // Source of the DocumentInternational Journal of Learning and Intellectual Capital. - 2016 . - N 13 (2-3). - pp. 119-134

[9] Zedtwitz, M. A typology of reverse innovation / Zedtwitz, M., Corsi, S.,Soberg, P.V., Frega, R. // Journal of Product Innovation Management. - 2016. - N 32 (1). - pp. 12-28.

[10] Regions of Russia. Socio-economic indicators. 2017: Stat.sb./Rosstat. M., 2017. - 1402 